\title{
Dìvān-e Ešrāq. Édité par Samīrā Pūstīndūz et introduit par Jūyā JahānbaȞšs, Tehrān, Mīrāt-e maktūb, 1385/2006, 142+176p. [Poèmes de l'illumination]
}

Ève Feuillebois-Piérunek

\section{(2) OpenEdition}

Journals

Édition électronique

URL : http://journals.openedition.org/abstractairanica/31562

DOI : 10.4000/abstractairanica.31562

ISSN : 1961-960X

Éditeur :

CNRS (UMR 7528 Mondes iraniens et indiens), Éditions de l'IFRI

Édition imprimée

Date de publication : 15 mai 2008

ISSN : 0240-8910

Référence électronique

Ėve Feuillebois-Piérunek, « Dĩvān-e Ešrāq. Édité par Samīrā Pūstīndūz et introduit par Jūyā Jahānbahšs, Tehrān, Mīrāt-e maktūb, 1385/2006, 142+176p. [Poèmes de l'illumination] », Abstracta Iranica [En ligne], Volume 29 | 2008, document 334, mis en ligne le 15 septembre 2008, consulté le 26 septembre 2020. URL : http://journals.openedition.org/abstractairanica/31562; DOI : https://doi.org/10.4000/ abstractairanica.31562

Ce document a été généré automatiquement le 26 septembre 2020.

Tous droits réservés 


\title{
Dīvān-e Ešrāq. Édité par Samīrā Pūstīndūz et introduit par Jūyā JahānbaȞš, Tehrān, Mīrāt-e maktūb, 1385/2006, 142+176p. [Poèmes de l'illumination]
}

\author{
Ève Feuillebois-Piérunek
}

1 Le célèbre philosophe Mīr Dāmād est également l'auteur d'un recueil de poèmes de style indien et de thématique métaphysique, connu jusqu'ici à travers l'édition malheureusement assez approximative de Ḥāj Mīrzā Mahmūd Šafīī (Ispahan, 1349). Samīrā Pūstīndūz propose ici une nouvelle édition critique à partir de trois manuscrits (Malek, Āstān-e Qods, 'Allāme Moḥaqqeq).

2 Jūyā JahānbaHšs nous fournit une copieuse introduction à la vie, à l'œuvre et à la postérité du grand philosophe. Il insiste sur la compatibilité de la pensée de Mīr Dāmād avec le shi'isme, mais sans présenter réellement sa pensée. On trouvera des considérations intéressantes sur le style indien et la prose safavide ainsi que sur le mariage entre 'erfān et philosophie à la période concernée.

INDEX

Thèmes: 11.1.1. Littérature persane classique 
AUTEURS

ÈVE FEUILLEBOIS-PIÉRUNEK

Sorbonne Nouvelle-Paris III / Mondes iranien et indien 